\title{
Correction to: Speculative Fiction and the Political Economy of Healthcare: Chang-Rae Lee's On Such a Full Sea
}

\section{Phillip Barrish ${ }^{1}$}

Published online: 29 June 2018

(C) Springer Science+Business Media, LLC, part of Springer Nature 2018

\section{Correction to: J Med Humanit https://doi.org/10.1007/s10912-018-9514-4}

Due to an editing error, this article was initially published with an incorrect title. The correct title is reflected above.

The original article has been corrected.

The online version of the original article can be found at https://oi.org/10.1007/s10912-018-9514-4

\section{Phillip Barrish}

pbarrish@austin.utexas.edu 